\title{
IN SILICO DRUG EVALUATION AND DRUG RESEARCH OF BIOACTIVE MOLECULE METHYL 4-BROMO-2- FLUOROBENZOATE
}

\author{
BIYYOAKTIF MOLEKÜL METIL 4-BROMO-2-FLOROBENZOAT'IN IN SİLIKO ILAÇ \\ DE GERLENDIRMESİ VE ARAŞTIRMASI
}

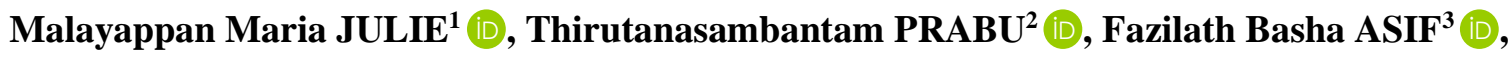 Sambanthan MUTHU ${ }^{45^{*}}$}

${ }^{1}$ Department of Physics, St. Joseph's College of Arts and Science, 607 001, Tamilnadu, India

${ }^{2}$ Department of Physics, A. V. C College (Autonomous), 609 305, Tamilnadu, India

${ }^{3}$ Department of Physics, Islamiah College (Autonomous), 635 752, Tamilnadu, India

${ }^{4}$ Department of Physics, Arignar Anna Govt. Arts College, 604 407, Tamil Nadu, India

${ }^{5}$ Department of Physics, Puratchi thalaivar Dr. M.G.R. Govt. Arts and Science College, 603 406,

Tamil Nadu, India

\begin{abstract}
Objective: The biochemical analysis plays an important role in pharmaceutical chemistry. Fungal infections are the most common infectious disease worldwide. The result of this research study can be very useful for the pharmacy and drug discovery process.

Material and Method: The experimental UV-Vis absorption is recorded with DMSO as solvent in SAIF IIT (Sophisticated Analytical Instrument Facility, Indian Institute of Technology, Chennai, India). Biologically active sites are reviewed by Gauss software via MEP. Toxic predictions are completed with the Preadme online tool. Protein-Ligand interaction was studied by Autodock tools 4.2.6.

Result and Discussion: Methyl 4-bromo-2-fluorobenzoate (MBF) molecule is structurally stable. Hydrogen binding sites of MBF molecule are found around carbonyl group. The HOMO/LUMO energy values are $-6.509 \mathrm{eV}$ and $-4.305 \mathrm{eV}$, respectively. Stabilization energy $(3.63 \mathrm{kcal} / \mathrm{mol})$ was calculated as $04=C 11$ atoms. Toxicity parameters are calculated. Overall results shows stabilized MBF molecule is intoxic and suitable for drug nature of fungal diseases.
\end{abstract}

Keywords: DFT, drug likeness, molecular docking, NBO, toxicity

\footnotetext{
* Corresponding Author/Sorumlu Yazar: Sambanthan Muthu e-mail / e-posta: mutgee@ gmail.com, Phone / Tel.: +914182225313
} 


\section{ÖZ}

Amaç: Biyokimyasal analiz farmasötik kimyada önemli bir rol oynar. Mantar enfeksiyonları dünya çapında en yaygın bulaşııı hastalıktır. Bu araştırma çalışmasının sonucu, eczacılık ve ilaç keşif süreci için çok faydalı olabilir.

Gereç ve Yöntem: Deneysel UV-Vis absorpsiyonu çözücü olarak DMSO kullanılarak SAIF IIT'de (Gelişmiş Analitik Cihaz Tesisi, Hindistan Teknoloji Enstitüsü, Chennai, Hindistan) kaydedildi. Biyolojik olarak aktif bölgeler, Gauss yazllımı tarafindan MEP aracılığıyla incelendi. Toksisite tahminlemesi Preadme çevrimiçi aract ile tamamlandi. Protein-Ligand etkileşimi Autodock 4.2.6 programuyla incelendi.

Sonuç ve Tartışma: Metil 4-bromo-2-florobenzoat (MBF) molekülü yapısal olarak kararlıdır. MBF molekülünün hidrojen bağlanma yerleri karbonil grubu çevresinde bulunur. HOMO/LUMO enerji değerleri, sirasiyla $-4,305 \mathrm{eV}$ ve $-6.509 \mathrm{eV}$ dir. Stabilizasyon enerjisi $(3.63 \mathrm{kcal} / \mathrm{mol})$ O4 $=$ C11 atomlarl olarak hesapland. Toksisite parametreleri hesaplandl. MBF molekülü ile mantar proteini arasında iki hidrojen bağı oluştu. Genel sonuçlar, stabilize edilmiş MBF molekülünün zehirli olmadığını ve mantar hastalıkları için ilaç olarak uygun olduğunu göstermektedir.

Anahtar Kelimeler: DFT, ilaç benzerliği, moleküler yerleştirme, NBO, toksisite

\section{INTRODUCTION}

Benzoates and their halogenated derivatives represent an interesting class of biologically active compounds [1-3]. The title molecule, methyl 4-bromo-2-fluorobenzoate (MBF) is a halogenated benzoate derivative. Halogenated benzoate dervatives have drawn much attention because of their medicinal acivities, such as antimicrobial [4] and anticancer [5]. In addition, benzyloxy-benzaldehyde derivates were tested against the HL-60cell line for anticancer activity [6]. Due to wide range of pharmaceutical application benzoate derivate attacts the attention of researches. Quantum chemical computations have been proved to cost effective tool for structural exploration of any biologically active compounds. The quantum chemical calculations of methyl 2,5-dichlorobenzoate has been proposed in the literature [7]. Bacterial degradation properties are reported earlier in the literature and plant fungal diseases are studied on related fluorobenzoate derivative [8, 9]. Sodium benzoate and benzoate derivatives were studied earlier on biological activity mainly, fungal activity [10,11]. From a through literature survey, In silico structure stable properties, pharmaceutical evaluations and biological behaviour of methyl 4-bromo-2-fluorobenzoate have been not reported so far.

In this present work, we report on optimized structure properties, chemical bond with stabilization [12] energy of bioactive headline compound. Band gap energies from molecular orbitals were calculated [13]. Pharmaceutical investigations like Drug likeness, Toxic and ADME properties, and Biochemical properties have explored. The electronic absorption spectrum of MBF has also been estimated using TD-DFT process. Furthermore, biologically active sites are identified from the electrostatic potential of MBF molecule [14], frontier molecular properties were investigated using theoretical calculations. Antifungal activity of MBF was studied by molecular docking method. 


\section{MATERIAL AND METHOD}

\section{Experimental details}

The pure sample of MBF [methyl 4-bromo-2-fluorobenzoate] was obtained from the SigmaAldrich company, India with $99 \%$ of purity. UV-visible absorption spectrum of the sample was recorded in the range from 200 to $700 \mathrm{~nm}$ using a Perkin Elmer Lambda 35 spectrophotometer with $1 \mathrm{~nm}$ resolution.

\section{Computational details}

All the calculations were carried out using the Gaussian'09 program package [15]. All Druglikeness and toxic prediction was completed by PreAdme [16]. Docked protein was downloaded from RSCB [17]. The computation of the atomic charges was done by Kollman and Gasteiger method after the polar hydrogenwas attached. The active with the Lamarckian Genetic Algorithm (LGA) being used to carry site of the proteinwas defined with $126 \AA$ x $126 \AA$ x $126 \AA$ grid size, out the process [18]. The docking calculations were carried out using the AutoDock 4.2 program software [19]. Proteinligand interaction was visualized with PyMol [20].

\section{RESULT AND DISCUSSION}

\section{Stabilized geometry}

Geometrical parameters explains bond properties [21], the optimized stable structure of headline compound is shown in Figure1. Stabilized global minimum energy is -3133.0601 Hartree. The title molecule has three substituents, namely fluorine, bromine and methyl carboxylate $\left(-\mathrm{CO}_{2} \mathrm{CH}_{3}\right)$ group, which are attached with benzene ring. In the present work, the bond length 1.910, 1.339, 1.355, 1.439, 1.206, 1.401, 1.404Å of Br1-C10, F2-C6, O3-C11, O3-C12, O4-C11, C5-C6, C5-C7. The highest bond length is predicted between as $\mathrm{Br} 1-\mathrm{C} 10$ with the value of $1.910 \AA$. The torsion angles are $179.9^{\circ}$ for (C6$\mathrm{C} 5-\mathrm{C} 11-\mathrm{O} 3), 0.0^{\circ}$ for $(\mathrm{C} 7-\mathrm{C} 5-\mathrm{C} 11-\mathrm{O} 3)$ and $179.9^{\circ}$ for (C5-C11-O3-C12). This conjugative charge transfer enhances the bioactivity of the MBF molecule. All the optimized structural parameters of MBF compound is given in Table.1.

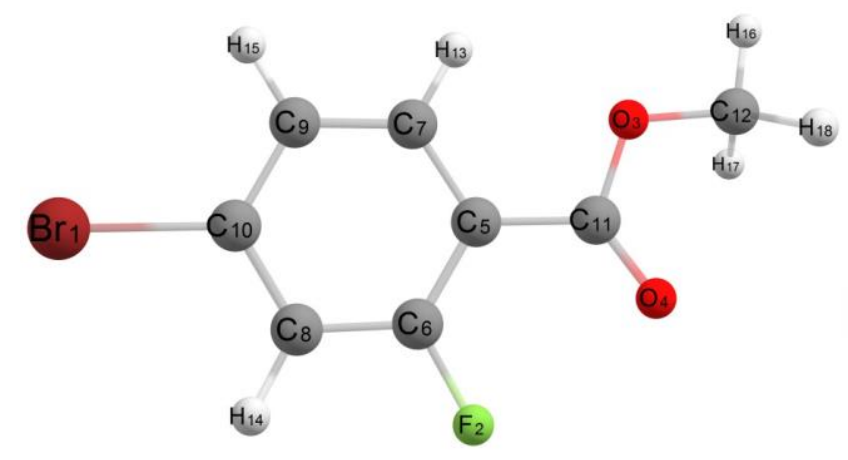

Figure 1. Stabilized geometrical structure of MBF molecule. 
Table 1. Stabilized geometrical parameters of MBF compound.

\begin{tabular}{|l|c|c|c|}
\hline \multirow{2}{*}{ Bond length } & Value $(\mathbf{\AA})$ & \multirow{2}{*}{ Bond angle } & Value $\left.\mathbf{(}^{\circ}\right)$ \\
\cline { 2 - 4 } & Calc. & & Calc. \\
\hline Br1-C10 & 1.910 & C6-C5-C11 & 121.71 \\
\hline F2-C6 & 1.339 & C7-C5-C11 & 121.33 \\
\hline O3-C11 & 1.355 & C6-C5-C7 & 116.96 \\
\hline O3-C12 & 1.439 & C5-C6-C8 & 122.40 \\
\hline O4-C11 & 1.206 & C8-C10-C9 & 121.26 \\
\hline C5-C6 & 1.401 & C7-C9-C10 & 118.79 \\
\hline C5-C7 & 1.404 & C5-C11-O3 & 111.20 \\
\hline C6-C8 & 1.389 & C11-O3-C12 & 115.63 \\
\hline C8-C10 & 1.389 & & Torsional angle \\
\hline C10-C9 & 1.393 & C6-C5-C11-O4 & 0.00 \\
\hline C9-C7 & 1.388 & C6-C5-C11-O3 & 179.99 \\
\hline C7-H13 & 1.081 & C5-C11-O3-C12 & 179.99 \\
\hline C9-H14 & 1.081 & C6-C5-C7-C9 & 0.00 \\
\hline C8-H15 & 1.081 & C5-C7-C9-C10 & 0.00 \\
\hline C12-H16 & 1.088 & C10-C8-C6-C5 & 0.00 \\
\hline C12-H17 & 1.091 & & \\
\hline C12-H18 & 1.091 & & \\
\hline
\end{tabular}

\section{Natural bond orbital analysis}

The Donor-acceptor interactions are important parameter study the lone pair electrons of chemical or biochemical structures [22]. The predicted parameters of donor accetptor interactions theoretically are $\pi(\mathrm{C}-\mathrm{C}), \pi(\mathrm{O}-\mathrm{C})$ and $\pi^{*}(\mathrm{C}-\mathrm{C})$ orbitals as a function in this intramolecular charge transfer causes the stabilization in the molecular system and it is responsible for responsible for bioactivity. This interactions are identified from the overlap of the orbitals of $\pi(\mathrm{O} 4-\mathrm{C} 11)$ to $\pi^{*}(\mathrm{C} 5-\mathrm{C} 6), \pi(\mathrm{C} 5-\mathrm{C} 6)$ to $\pi^{*}(\mathrm{C} 8-\mathrm{C} 10)$ and $\pi(\mathrm{C} 8-\mathrm{C} 10)$ to $\pi^{*}(\mathrm{C} 7-\mathrm{C} 9$. The energy values of these interactions are shown in Table 2.

Table 2. Calculated stabiliazation energy between bonds by NBO method.

\begin{tabular}{|c|c|c|c|c|c|c|}
\hline \multicolumn{2}{|c|}{ Donor-i } & \multicolumn{2}{|c|}{ Acceptor-j } & \multirow{2}{*}{$\begin{array}{c}\mathrm{E}(2)^{\mathrm{a}} \\
\mathrm{kcal} / \mathrm{mol}\end{array}$} & \multirow{2}{*}{$\begin{array}{c}\mathbf{E}(\mathbf{j})-\mathbf{E}(\mathbf{i})^{\mathbf{b}} \\
\text { (a.u.) }\end{array}$} & \multirow{2}{*}{$\begin{array}{l}\mathbf{F}(\mathbf{i}, \mathbf{j})^{\mathbf{c}} \\
\text { (a.u.) }^{\text {a.u }}\end{array}$} \\
\hline Bonds & (Occupancy) & Bonds & (Occupancy) & & & \\
\hline \multirow[t]{4}{*}{$\mathrm{n} 1(\mathrm{O} 3)$} & 1.96360 & $\sigma^{*}(\mathrm{C} 12-\mathrm{H} 16)$ & 0.00907 & 2.31 & 0.96 & 0.042 \\
\hline & & $\sigma^{*}(\mathrm{C} 12-\mathrm{H} 17)$ & 0.01329 & 4.60 & 0.72 & 0.054 \\
\hline & & $\sigma^{*}(\mathrm{C} 12-\mathrm{H} 18)$ & 0.01340 & 4.78 & 0.72 & 0.055 \\
\hline & & $\sigma^{*}(\mathrm{C} 7-\mathrm{H} 113)$ & 0.01156 & 2.78 & 2.07 & 0.070 \\
\hline $\mathrm{n} 2(\mathrm{O} 4)$ & 1.85367 & $\sigma^{*}(\mathrm{C} 5-\mathrm{C} 11)$ & 0.05584 & 14.95 & 0.72 & 0.094 \\
\hline$\pi(\mathrm{O} 4=\mathrm{C} 11)$ & 1.98078 & $\pi^{*}(\mathrm{C} 5-\mathrm{C} 6)$ & 0.41107 & 3.63 & 0.39 & 0.037 \\
\hline \multirow[t]{2}{*}{$\pi(\mathrm{C} 5-\mathrm{C} 6)$} & 1.63072 & $\pi^{*}(\mathrm{C} 7-\mathrm{C} 9)$ & 0.30312 & 21.18 & 0.30 & 0.072 \\
\hline & & $\pi^{*}(\mathrm{C} 8-\mathrm{C} 10)$ & 0.39699 & 19.25 & 0.28 & 0.066 \\
\hline \multirow[t]{2}{*}{$\pi(\mathrm{C} 7-\mathrm{C} 9)$} & 1.66006 & $\pi^{*}(\mathrm{C} 5-\mathrm{C} 6)$ & 0.41107 & 19.03 & 0.27 & 0.065 \\
\hline & & $\pi^{*}(\mathrm{C} 8-\mathrm{C} 10)$ & 0.39699 & 22.79 & 0.26 & 0.070 \\
\hline \multirow[t]{2}{*}{$\pi(\mathrm{C} 8-\mathrm{C} 10)$} & 1.68638 & $\pi^{*}(\mathrm{C} 5-\mathrm{C} 6)$ & 0.41107 & 20.42 & 0.29 & 0.070 \\
\hline & & $\pi^{*}(\mathrm{C} 7-\mathrm{C} 9)$ & 0.30312 & 17.22 & 0.30 & 0.064 \\
\hline
\end{tabular}

${ }^{a} \mathrm{E}(2)$ hyperconjugative interactions energy.

${ }^{\mathrm{b}}$ Donor and acceptor differences (i)-(j) NBO orbitals.

${ }^{\mathrm{c}} \mathrm{F}$ i,j Fock matrix element (i)-(j) NBO orbitals. 
The lone pair interactions $\mathrm{LP}(1)$ carboxylate $\mathrm{O} 3$ to antibondings $\sigma^{*}(\mathrm{C} 7-\mathrm{H} 13)$ with stabilization energy $2.78 \mathrm{kcal} / \mathrm{mol}$. This transfer of charge confirms the existence of $\mathrm{C} 7-\mathrm{H} 13 \cdots \mathrm{O} 3$ intramolecular hydrogen bonding.

\section{Eelectronic properties}

The FMO theory is important in defining the reactivity, bioactivity, and electronic properties of organic compounds. The HOMO energy represents to the being able to donate an electron [23, 24]. The HOMO-LUMO plots MBF is shown in Figure 2. The HOMO/LUMO energy values are-6.509eV along$4.305 \mathrm{eV}$, respectively. The lowering energy gap authenticates the charge transfer within the MBF molecule. The bioactivity of MBF was verified by the discovery difference in energy value $2.204 \mathrm{eV}$. The lower band gap energy of MBF compound is comparable with the bioactive materials. From the HOMO-LUMO energy values the global chemical reactivity descriptors such as electronegativity $(\chi)$, global hardness $(\eta)$, global softness (S) and electrophilicity index ( $\omega$ ) of MBF are $0.1459,0.1301,0.5203$ and -0.0818 , respectively.

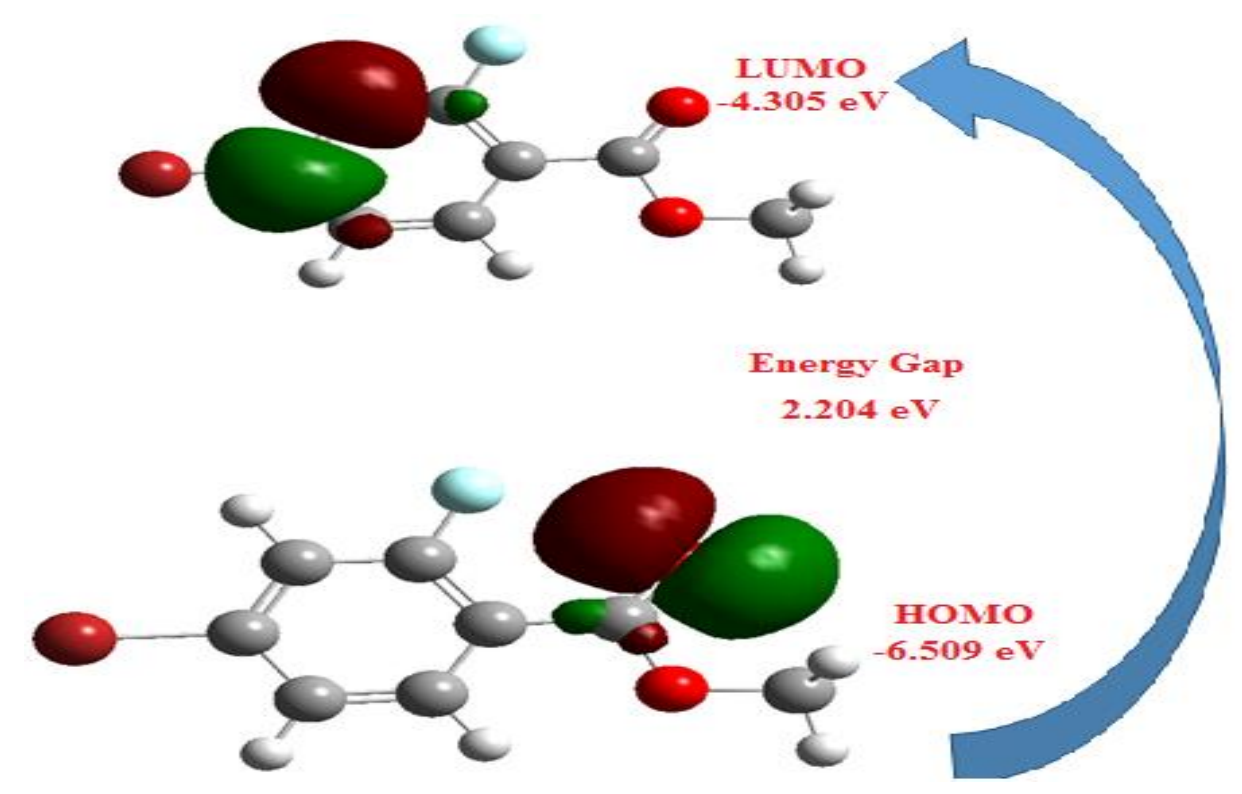

Figure 2. HOMO-LUMO orbitals of MBF molecule with bandgap energy.

The UV-Vis absorption spectrum recorded by using DMSO solvent and compared with the computed spectrum of MBF by same level theory. Predicted parameters like, excitation energies, absorption maxima are shown in Table 3. The compared UV-visible absorption spectrum of MBF compound is shown in Figure 3. The band gap value is $1.707 \mathrm{eV}$ calculated using Tauc's plot method [25], the measured UV-vis spectrum agrees well with the simulated HOMO-LUMO energy difference $2.204 \mathrm{eV}$. 
Table 3. Absorption wavelength and excitation energies of MBF molecule.

\begin{tabular}{|c|c|c|c|c|}
\hline \multicolumn{2}{|c|}{ Wavelength(nm) inDMSO } & $\begin{array}{c}\text { Energy } \\
(\mathbf{e V})\end{array}$ & Oscillator-strength (f) & Transition (assignments) \\
\cline { 1 - 2 } Theoretical & Experimental & 4.7362 & 0.1618 & $\begin{array}{c}\text { H-1->LUMO (36\%), } \\
\text { HOMO->LUMO (47\%), } \\
\text { HOMO->L+1 (12\%) } \\
\text { H-1->L+1 (3\%) }\end{array}$ \\
\hline 262 & 297 & & & $\begin{array}{c}\text { H-2->LUMO (96\%) } \\
\text { H-2->L+6 (3\%) }\end{array}$ \\
\hline 256 & 271 & 4.8347 & 0.0001 & $\begin{array}{c}\text { H-1->LUMO (42\%), } \\
\text { HOMO->LUMO (48\%) } \\
\text { HOMO->L+1 (8\%) }\end{array}$ \\
\hline
\end{tabular}

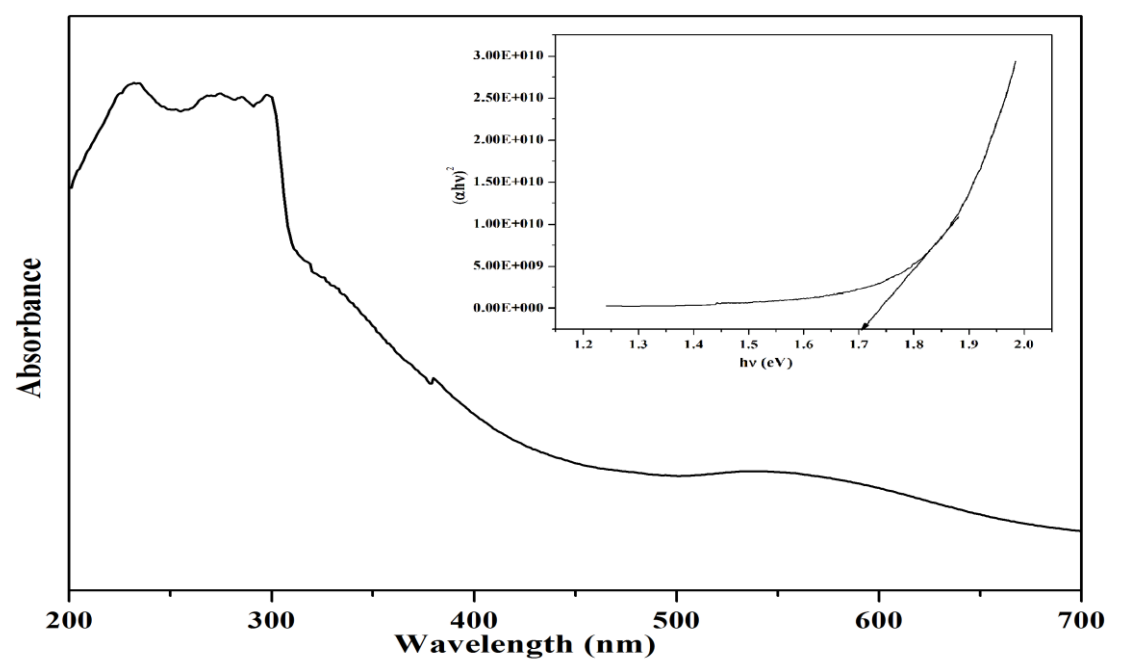

Figure 3. UV-Vis spectrum of MBF molecule.

\section{MEP analysis}

MEP surface analysis provides information on a molecule's chemical reactivity and its uses allows limit to predict the electrophilic and nucleophilic attacks of any chemical compound [26, 27]. The MEP surface is shown in Figure 4 with electron density range of $-5.552 \mathrm{e}^{-2}$ (red) to $5.552 \mathrm{e}^{-2}$ (blue). The electrophilic sites are predicted on the surface of carbonyl group in MPF compound. Atom O4 in carbonyl is expected to have more bioactivity with the molecule due its electrophility.

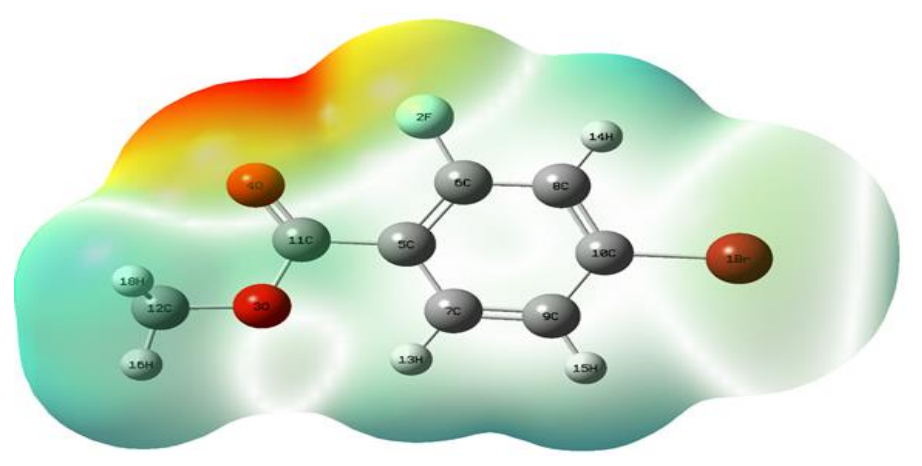

Figure 4. MEP surface of MBF molecule. 


\section{ADME}

Absorption, Distribution, Metabolism and Excretion properties of a chemical structure are important parameters in pharmaceutical research [28]. Solute permeability (Blood Brain Barrier) value is 1.91742 , while the buffer solubility is 11218 . The Caco2 is 20.4652, CYP 2C19, CYP 2C9 are an inhibitor, HIA $n$ value is 98.447181 , MDCK is 0.277822 , Plasma protein binding is 70.38 , pure water solubility is 552.998 , Skin permeability is -1.98533 , SK $\log \mathrm{D}$ value is 1.40496 , and SKlogP value is 2.65296. The Plasma protein binding value is within the limit for the headline compound, which also has a reputed role in therapeutic uses and recommendations pharmacokinetics drug metatbolism [29].

\section{Drug likeness properties}

In drug discovery process the drug likeness properties has effective role in the production of active drugs [30]. By comparing the values reported with parameters, HIA value between 70 and 100\% shows good human intestinal absorption and for this molecule it is $96.91 \%$. Caco-2 and MDCK cell permeability are two predicted parameters for oral absorption of drugs. The computed Caco- 2 cell permeability value is $21.803 \mathrm{~nm} / \mathrm{s}$ and MDCK cell permeability value is $0.5697 \mathrm{~nm} / \mathrm{s}$ respectively. The inhibited P-glyco protein value for the molecule shows that the inhibitor and the protein were responsible for the pharmacokinetic properties of the drug. The analysis of pure water solubility is $2370.34 \mathrm{mg} / \mathrm{L}$. The cytochrome protein indicates that the molecule is inhibitor of 2C19, 2C9 and 3A4 which reduces the capability of the drug and pharmacological effects of the drug [9]. In present the different types of rules are implemented to study violations of the headline compound. The Lead-like has suitable of its binding affinity is greater than 0.1 microM and it has zero violations, MDDR like rule shows the nondrug-like nature, because of no rings, no rigid bonds, no rotatable bonds, while the important rule of five shown that hydrogen bond donors and hydrogen bond acceptors are less than five in headline molecule, molecular mass is lessthan 500, which shows that the Lipinski rule has no violations and this molecule is suitable for drug discovery procedure. Moreover the WDI like rule is out of $90 \%$ cutoff. Overall, the of MBF structure druglikeness properties shows as a suitable compound for drug discovery procedure.

\section{Toxicity}

Toxic prediction plays crucial role in drug discovery process and it is important parameters to identify the intoxic nature of various chemical compounds [31]. For the MPF compound algae at value is 0.051268 , Ames test is as usual mutagen and the important carcino mouse is negative and the carcino rat is positive. The daphnia at value is 0.195 , while the $h E R G$ is at low risk inhibition stage. The medaka at and minnow at values are 0.0526 and 0.028 , respectively. All the above values are compared with the resultant parameters of reported literature. All the predicted toxic parameters values show the in toxic nature in the compound. 


\section{Ramachandran plot}

Satistical distributions of amino acids in protein crystal structure can be studied from Ramachandra plot. In present study the Pass online bio activity predictor $[32,33]$ is used to find the inhibition activity of the MBF compound. The protein 4FPR is chosen study the PL interaction and it is subjected to find the quality of protein. Most of the amino acids are fall within the allowed region of 4FPR crystal structure. This shows the crystal structure of protein is stable in nature. The allowed regions of 4FPR protein residues are shown in Figure 5.

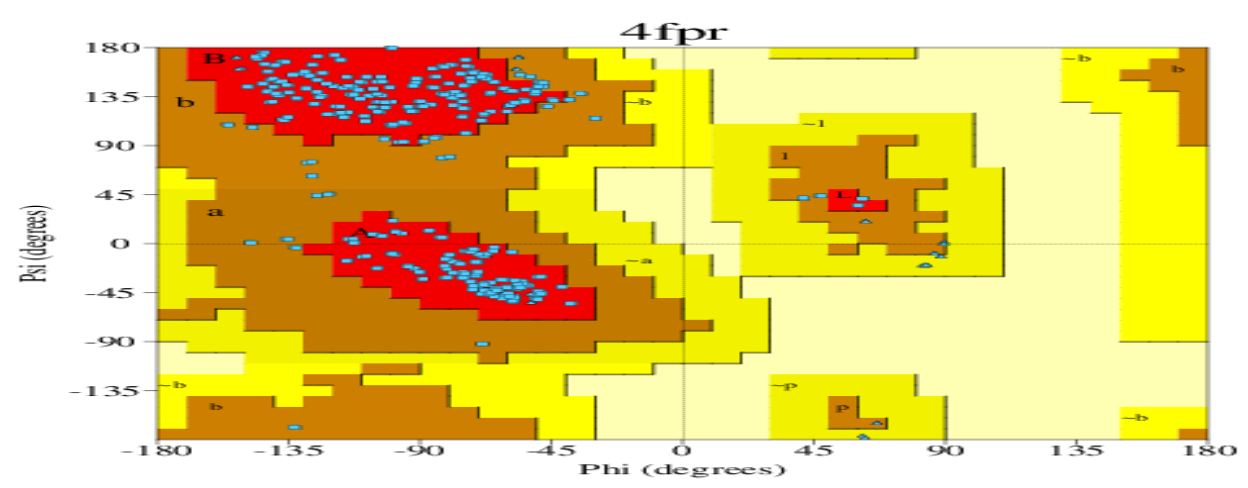

Figure 5. 2D Ramachandra plot for fungal protein structure (4FPR).

\section{Molecular docking study}

Molecular docking plays prominent role in drug design for treating of many diseases [34, 35]. In this process, we have explored the binding of a molecule with protein and thus effectively act as a drug and so docking has a great importance in the field of drug discovery. In present case, MBF compound is subjected to dock with the 4FPR fungal protein. Fungal disease is an infectious disease across the world. Piperazine derivative was investigated and reported for fungal activity with -4.73 $\mathrm{kcal} / \mathrm{mol}$ binding with single hydrogen bond interaction [36]. The MBF ligand forms two hydrogen bonds the chosen protein structure. Hydrogen bond interacted image is shown in Figure 6.

The atom $\mathrm{O} 4$ forms the bonds with the distance of $2.0 \AA$ and $1.8 \AA$ with the residues SER'28, and GLU' 130 , respectively. The binding energy $-5.00 \mathrm{kcal} / \mathrm{mol}$ is recorded as highest binding energy in this PL interaction. Hence, this MBF compound is predicted as potential drug candidate for fungal disease and bioactivy of the headline compound is confirmed. 


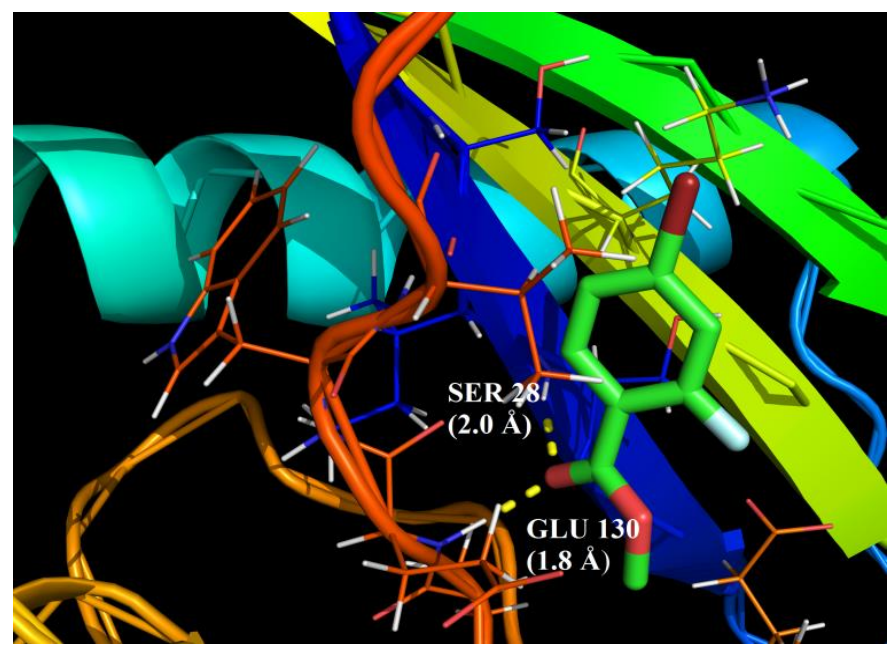

Figure 6. Hydrogen bond interacted image of MBF ligand with receptor fungal protein 4FPR.

In this study we investigated, structural properties (bond length between each atoms) of methyl 4-bromo-2-fluorobenzoate by optimizing the structure using DFT tools. The bioactive conformation revealed the existence of $\mathrm{C}-\mathrm{H} \cdots \mathrm{O}$ hydrogen bonding in between halo-benzene hydrogen and carboxylate oxygen, which confirmed through NBO study. Calculated band gap energy $(1.707 \mathrm{eV})$ from absorption spectra is compared with the band gap energy of HOMO-LUMO and which comparable with biologically active molecules. Different parameters like Solute permeability (Blood Brain Barrier) value are 1.91742, while the buffer solubility is 11218 of MBF compound is calculated from ADME properties. In drug likeness predictions, the Lipinski rule of five has no violation and the all the rules are suitable on the headline compound for drug nature. Carcino mouse is negative, which shows intoxic nature of MPF compound. Molecular docking result corroborates this result with $-5.00 \mathrm{kcal} / \mathrm{mol}$ binding energy. Hence the MPF compound and docked protein is structurally stable and form hydrogen bond between each other. So, we predict MPF compound might be a potential anti fungal drug candidate for fungal disease.

\section{AUTHOR CONTRIBUTIONS}

Conception: M.M.J., F.B.A.; Design: M.M.J., F.B.A.; Supervision: T.P., S.M.; Resources: T.P., S.M.; Materials: T.P., S.M.; Data collection and/or processing: M.M.J., F.B.A.; Analysis and/or interpretation: M.M.J.; Literature search: M.M.J.; Writing manuscript: M.M.J., F.B.A.; Critical review: M.M.J., T.P.; Other: M.M.J., F.B.A.

\section{CONFLICT OF INTEREST}

The authors declare no conflict of interest. 


\section{REFERENCES}

1. Hudlicky, M., Pavalath, A.E. (1995). Chemistry of organic Fluorine Compounds II.A Critical Review, American Chemical Society, Washigton, DC.

2. Banks, R.E., Smart, B.E., Tatlow, J.C. (1994). Organoflourine Chemistry: Principals and Applications, Plenum Press, New York.

3. Edwards, P.N. (1994). Uses of Flourine in Chemotherapyin Organoflouine Chemistry: Principles and Applications, Plenum Press, New York.

4. Ankersen, M., Peschke, B., Hansen, S.B., Hansen, T.K. (1997). Investigation of bioisosters of the growth hormone secretagogue L-692,429. Bioorganic Medicinal Chemistry Letters, 7, 1293 1298. https://doi.org/10.1016/S0960-894X(97)00216-3

5. Revesz, L., Blum, E., Di Padova, F.E., Buhl, T., Feifel R., Gram, H., Hiestand, P., Manning, U., Rucklin, G. (2004). Novel p38 inhibitors with potent oral efficacy in several models of rheumatoid arthritis. Bioorganic Medicinal Chemistry Letters, 14, 3595-3599. https://doi.org/10.1016/j.bmcl.2004.03.106

6. Lin, F.C., Yang, J.S., Chang, C.Y., Kuo, C.S., Lee, R.M., Huang, J.L. (2005). Synthesis and anticancer activity of benzyloxybenzaldehyde derivatives against HL-60 cells. Bioorganic Medicinal Chemistry, 13, 1537-1544. https://doi.org/10.1016/j.bmc.2004.12.026

7. Xuanand, X., Zhai, C. (2011). Quantum chemical studies of FT-IR and Raman spectra of methyl 2, 5- dichlorobenzoate. Spectrochimica Acta A, 79, 1663-1668. https://doi.org/10.1016/j.saa.2011.05.032

8. Oltmanns, R.H., Müller, R., Otto, M.K., Lingens, F. (1989). Evidence for a new pathway in the bacterial degradation of 4-fluorobenzoate. Applied and Environmental Microbiology, 55(10), 2499-2504. https://doi.org/10.1128/AEM.55.10.2499-2504.1989

9. Schlömann, M., Schmidt, E., \& Knackmuss, H. J. (1990). Different types of dienelactone hydrolase in 4-fluorobenzoate-utilizing bacteria. Journal of Bacteriology, 172(9), 5112-5118. https://doi.org/10.1128/jb.172.9.5112-5118.1990

10. Shimazaki, A., Sakamoto, J.J., Furuta, M., Tsuchido, T. (2016). Antifungal Activity of Diglycerin Ester of Fatty Acids against Yeasts and Its Comparison with Those of Sucrose Monopalmitate and Sodium Benzoate. Biocontrol Science, 21(2), 123-130. https://doi.org/10.4265/bio.21.123

11. Korošec, B., Sova, M., Turk, S., Kraševec, N., Novak, M., Lah, L., Stojan, J., Podobnik, B., Berne, S., Zupanec, N., Bunc, M., Gobec, S., Komel, R. (2014). Antifungal activity of cinnamic acid derivatives involves inhibition of benzoate 4-hydroxylase (CYP53). Journal of Applied Microbiology, 116(4), 955-966. https://doi.org/10.1111/jam.12417

12. Glendening, P.E.D., Reed, A.E., Carpenter, J.E., Weinhold, F. (1998). NBO Version 3.1, Theoretical Chemistry Institute and Department of Chemistry, University of Wisconsin, Madison.

13. Asif, F.B., Khan, F.L.A., Muthu, S., Raja, M. (2021). Computational evaluation on molecular structure (Monomer, Dimer), RDG , ELF , electronic (HOMO-LUMO, MEP) properties, and 
spectroscopic profiling of 8-Quinolinesulfonamide with molecular docking studies. Computational and Theoretical Chemistry, 113169. https://doi.org/10.1016/j.comptc.2021.113169

14. Fathima, R.B., Prasana, J.C., Muthu, Abraham, C.S. (2019). Molecular docking studies, charge transfer excitation and wave function analyses (ESP, ELF, LOL) on valacyclovir: A potential antiviral drug. Computational Biology Chemistry, 78, 9-17. https://doi.org/10.1016/j.compbiolchem.2018.11.014

15. Frisch, M.J., Trucks G.W., Schlegel, H.B., Scuseria G.E., Robb M.A., Cheeseman J.R., Ortiz J.V., Cioslowski J, Fox D.J. (2009). Gaussian 09, Revision A.02,. Gaussian, Inc., Wallingford CT.

16. Viana Nunes, A.M., das Chagas Pereira de Andrade, F., Filgueiras, L.A., de Carvalho Maia, O.A., Cunha, R.L.O.R., Rodezno, S.V.A., Maia Filho, A.L.M., de Amorim Carvalho, F.A., Braz, D.C., Mendes, A.N. (2020). preADMET analysis and clinical aspects of dogs treated with the Organotellurium compound RF07: A possible control for canine visceral leishmaniasis? $\begin{array}{lllll}\text { Environmental Toxicology and Pharmacology, } & 80, & 103470 .\end{array}$ https://doi.org/10.1016/j.etap.2020.103470

17. Berman, H.M., Westbrook, J., Feng, Z., Gilliland, G., Bhat, T.N., Weissig, H., Shindyalov, I.N., Bourne, P.E. (2000). The Protein Data Bank. Nucleic Acids Research, 28(1), 235-242. https://doi.org/10.1093/nar/28.1.235.

18. K V, Aarthi., Rajagopal, H., Muthu, S., Jayanthi, V., Girija, R. (2020). Quantum chemical calculations, spectroscopic investigation and molecular docking analysis of 4-chloro-Nmethylpyridine-2-carboxamide. Journal of Molecular Structure, 1210, 128053. https://doi.org/10.1016/j.molstruc.2020.128053

19. Morris, G.M., Huey R., Lindstrom, W., Sanner, M.F., Belew, R.K., Goodsell, D.S., Olson A.J. (2009). AutoDock4 and AutoDockTools 4: Automated docking with selective receptor flexibility. Journal of Computational Chemistry, 16, 2785-2791. https://doi.org/10.1002/jcc.21256

20. The PyMOL Molecular Graphics System, Version 1. 5.0.4, Schrodinger, LLC, 2009.

21. Al-Zaqri, N., Pooventhiran T., Alsalme, A., Warad I., John A.M., Thomas R. (2020). Structural and physico-chemical evaluation of melatonin and its solution-state excited properties, with emphasis on its binding with novel coronavirus proteins. Journal of Molecular Liquids, 318, 114082. https://doi.org/10.1016/j.molliq.2020.114082

22. Thomas, R., Hossain, M., Mary, Y.S., Resmi, K.S., Armaković, S., Armaković, S.J., Nanda, A.K., Ranjan, V.K., Vijayakumar, G., Alsenoy, C.V. (2018). Spectroscopic analysis and molecular docking of imidazole derivatives and investigation of its reactive properties by DFT and molecular dynamics simulations. Journal of Molecular Structure, 1158, 156-175. https://doi.org/10.1016/j.molstruc.2018.01.021

23. Pandey, M., Muthu, S., Nanje Gowda N.M. (2017). Quantum mechanical and spectroscopic (FT-IR, FT-Raman,1H,13C NMR, UV-Vis) studies, NBO, NLO, HOMO, LUMO and Fukui function analysis of 5-Methoxy-1H-benzo[d]imidazole-2(3H)-thione by DFT studies, Journal of Molecular Structure, $1130, \quad 511-521$. https://doi.org/https://doi.org/10.1016/j.molstruc.2016.10.064 
24. Asif, F.B., Khan, F.L.A., Muthu, S., Raja, M. (2020). Elaborated molecular structure, molecular docking and vibrational spectroscopic investigation of $\mathrm{N}$-((4-aminophenyl)sulfonyl)benzamide with Density functional theory. Chemical Data Collections, 31, 100609. https://doi.org/10.1016/j.cdc.2020.100609

25. Jeeva, S., Muthu, S., Tamilselvan, S., Caroline, M.L., Purushothaman, P., Sevvanthi S., Vinitha G., Mani G. (2018). Growth, spectroscopic studies, and third order non-linear optical analysis of an organic dicarboxylic acid based single crystal: Urea Oxalic acid. Chinese Journal of Physics, 56, 1449-1466. https://doi.org/10.1016/j.cjph.2018.05.021

26. Politzer, P., Truhlar D. (2013). Chemical Applications of Atomic and MolecularElectrostatic Potentials: Reactivity, Structure, Scattering, and Energetics of Organic, Inorganic, and Biological Systems, Springer Science Business Media.

27. Murray, J.S., Sen, K. (1996). Molecular Electrostatic Potentials Conceptsand Applications, Elsevier Science B.V., Amsterdam.

28. Shah, U., Patel, S., Patel, M., Gandhi, K., Patel, A. (2020). Identification of chalcone derivatives as putative non-steroidal aromatase inhibitors potentially useful against breast cancer by molecular docking and ADME prediction. Indian Journal of Chemistry -Section B, 59, 283293.

29. Psimadas, D., Georgoulias, P., Valotassiou, V., Loudos, G. (2012). Molecular Nanomedicine Towards Cancer. Journal of Pharmaceutical Science, 101, 2271-2280. https://doi.org/10.1002/jps

30. Abraham, C.S., Muthu, S., Prasana, J.C., Armaković, S.J., Armaković, S., Rizwana, F.B., B.G. Ben. (2018). Spectroscopic profiling (FT-IR, FT-Raman, NMR and UV-Vis), autoxidation mechanism (H-BDE) and molecular docking investigation of 3-(4-chlorophenyl)-N,Ndimethyl-3-pyridin-2-ylpropan-1-amine by DFT/TD-DFT and molecular dynamics: A potential SSRI drug. Computational Biology Chemistry, 77, 131-145. https://doi.org/10.1016/j.compbiolchem.2018.08.010

31. Thomas, R., Mary, Y.S., Resmi, K.S., Narayana, B., Sarojini, B.K., Vijayakumar, G., Van Alsenoy, C. (2020). Two neoteric pyrazole compounds as potential anti-cancer agents: Synthesis, electronic structure, physico-chemical properties and docking analysis. Journal of Molecular Structure, 1181, 455-466. https://doi.org/10.1016/j.molstruc.2019.01.003

32. Pooventhiran, T., Bhattacharyya, U., Rao, D.J., Chandramohan, V., Karunakar, P., Irfan, A., Mary, Y.S., Thomas, R. (2020). Detailed spectra, electronic properties, qualitative non-covalent interaction analysis, solvatochromism, docking and molecular dynamics simulations in different solvent atmosphere of cenobamate, Structural Chemistry, 31, 2475-2485. https://doi.org/10.1007/s11224-020-01607-8

33. Thomas, R., Mary, Y.S., Resmi, K.S., Narayana, B., Sarojini, S. B. K., Armaković, S.,. Armaković, S. J, Vijayakumar, G., Van Alsenoy, C., Mohan, B.J. (2019). Synthesis and spectroscopic study of two new pyrazole derivatives with detailed computational evaluation of their reactivity and pharmaceutical potential. Journal of Molecular Structure,1181, 599-612. https://doi.org/10.1016/j.molstruc.2019.01.014.

34. Thamarai, A., Vadamalar, R., Raja, M., Muthu, S., Narayana, B., Ramesh, P., Sevvanthi, S., Aayisha, S. (2020). Molecular structure conformational analyses, solvent-electronic studies 
through theoretical studies and biological profiling of (2E)-1-(3-bromo-2-thienyl)-3-(4chlorophenyl)-prop-2-en-1-one. Journal of Molecular Structure, 1202, 127349. https://doi.org/10.1016/j.molstruc.2019.127349

35. Chandralekha, B., Hemamalini, R., Muthu, S., Sevvanthi, S. (2020). Spectroscopic (FT-IR, FTRAMAN, NMR, UV-Vis) investigations, computational analysis and molecular docking study of 5-bromo-2-hydroxy pyrimidine. Journal of Molecular Structure, 1218, 128494. https://doi.org/10.1016/j.molstruc.2020.128494

36. Raajaraman, B.R., Sheela, N.R., Muthu, S. (2018). Investigation on 1-Acetyl-4-(4hydroxyphenyl) piperazine an anti-fungal drug by spectroscopic, quantum chemical computations and molecular docking studies. Journal of Molecular Structure, 1173, 583-595. https://doi.org/10.1016/j.molstruc.2018.07.030 